$\frac{\mathrm{DE}}{\mathrm{G}}$

DOI: $10.2478 / a a-2014-0010$

\title{
Imaginative Communities: The Role, Practice and Outreach of Community-Based Theatre
}

\section{Ivan Lacko}

Ivan Lacko is an assistant professor at the Department of English and American Studies at the Faculty of Arts at Comenius University in Bratislava where he teaches courses in American studies and literature. His most recent interests include, but are not limited to, political theatre and performance, and the social and political impact of art in general.

\begin{abstract}
In recent years, the artistic representation of communities (e.g. in community-based theatres) has found its source in the realm of the imagination (documentary drama, verbatim theatre, post-dramatic performance, etc.), addressing issues that are important and relevant not only for the communities themselves but also for the wider society. In this presentation I will use Zygmunt Bauman's notion of the "seductive lightness of being" - or the transitory nature of our virtual experience - to talk about the role of selected community-based theatres in the United States and about their imaginative depiction and discussion of issues which are of vital importance for any community: identity, the personal vs. the political, a sense of belonging, progressiveness, social awareness and the capability of coexistence.
\end{abstract}

In his 2000 book Liquid Modernity, eminent sociologist Zygmunt Bauman speaks about the fluidity and evanescence of the new, computerized life in the $21^{\text {st }}$ century. For Bauman, the "instantaneous time of the software world is also an inconsequential time" and the accelerated pace of living requires "[not only] immediate, 'on-the-spot' fulfilment - but also immediate exhaustion and fading of interest. [...] There are only 'moments' - points without dimensions" (Bauman, 2000, p. 118). This, in turn, redefines the social awareness of people and their interaction within communities. While on a national level, the social fragmentation and superficiality discussed by Bauman reflects a substantial portion of the discourse on nations as imagined communities, as contemplated by Benedict Anderson (Anderson, 2006, p. 7), on the level of smaller, more distinctive communities, it is harder to name and examine. The transient nature of social interaction and political engagement in the $21^{\text {st }}$ century is more suitable for the medium of theatre.

In this paper, I would like to argue that theatre, in particular community and communitybased theatre, can respond to (and potentially also satisfy) the demand for instant engagement and gratification when communities are faced with issues of social, economic and political relevance. In order to do this, I will endeavour to discuss theories of community-based performance, of performance in a general sense, as well as of political and social theatre, and subsequently apply them to the work of three selected theatre companies performing in Minneapolis, USA (Mixed Blood Theatre, Pangea World Theater, Pillsbury House Theatre). Rather than being "imagined", the communities from and for which the above mentioned theatres work are involved, engaged, critical, and, above all, imaginative. 


\section{Instant Imagination}

The subject of my scrutiny is the artistic and cultural expression of urban communities living in the city of Minneapolis, mostly communities of a specific ethnic, racial and social background. The communities I will be examining are rather broad to define specifically, and I will have to refrain from investigating the rules and idiosyncrasies underlying their establishment. I am solely interested in the theatrical representation of the issues these communities are concerned with.

David Diamond defines a community as a social group that "shares geography, values, experiences, expectations or beliefs" and has become part the community as a result of a process that was either "voluntary or involuntary" because people can often be "simply born into a community" and "[one] person can be a member of many different communities" (Diamond, 2007, p. 47). Such a definition is inherently loose in its scope because communities can overlap, particularly when it comes down to the specific issues or problems they face.

For Bauman, the term "community" and its meaning has undergone great and varied development and is nowadays "the last relic of the old-time utopias of the good society; it stands for whatever has been left of the dreams of a better life shared with better neighbours all following better rules of cohabitation" (Bauman, 2000, p. 92). In the hope of a better life and improved social and living standards, communities are keen to discuss issues that concern them using a variety of artistic platforms. The platform of community-based or social theatre has been constructed from a dialectic relationship between community and social theatre forms and forms of the traditional aesthetic theatre. ${ }^{i}$ James Thomson and Richard Schechner define the groups involved in social theatre as an assortment of "local residents, disabled people, young prisoners, and many other groups often from vulnerable, disadvantaged, and marginalized communities," often also including "individuals who have lost touch with a sense of groupness, who are internally as well as externally displaced and homeless" (Thomson \& Schechner, 2004, p. 12).

Community-based theatre derives its existence from the ability and willingness to reflect issues that are essential for the life, awareness and identity of a specific community, and "community-based production[s] [are] usually a response to a collectively significant issue or circumstance" (Cohen-Cruz, 2005, p. 2). This ambition offers community productions the possibility to employ aesthetics that grow out of a need to raise political issues, to deal with power relations, to face ideologies - in short, to address specific and momentary issues rather than questions of eternal significance and universal appeal. Community shows steer away from the psychological realism of the big stage and display an inclination towards Brechtian epic theatre, interactive productions and purely performative pieces.

When community members go to see a theatre show, their participation (and sometimes even involvement) establishes public dialogue that not only engages and raises awareness but also provides entertainment and reflection through themes the audience can easily identify with. Jill Dolan's examination of how performance can bring audience a sense of hope and utopia presents the idea that "such spectatorship might encourage [audiences] to be active in other public spheres, to participate in civic conversations that performance perhaps begins" (Dolan 2005:11). Often, performance itself can fuel the aims and motivations of community-based aesthetics. Jan Suk, in his examination of the work of British performance ensemble Forced Entertainment, discusses the symbiotic relationship between the performers and their audience and refers to it as "[a] shared conspiratory feeling of fulfilling no ambitions, requirements, obligations" which allows the actors to perform on the basis of and "respond[ing] to the fact that they are being watched" (Suk, 2014, p. 58).

The response of community-based theatres to social and political issues that are relevant for the communities in question satisfies the need for instantaneity as posited by Bauman. The 
three Minneapolis-based theatres I mentioned above reflect the topical discussions in two to three productions every year. In the following analysis I will focus on three shows: Learn to Be Latina (2012) by Mixed Blood Theatre, Outside the Circle (2012) by Pangea World Theater, and Buzzer (2012) by Pillsbury House Theatre. The community-relevant issues discussed by the productions include, but are not limited to, ethnic and national identity (Learn to Be Latina); homosexuality, physical disability and intolerance (Outside the Circle); and the social complexities of gentrification and post-raciality (Buzzer).

\section{Community and Hospitality}

Learn to Be Latina is a 2012 production of the Mixed Blood Theatre - a well-known and well-established theatre present on the Minneapolis scene since 1976. The play, written by Enrique Urueta, explores the frailty of the public identity of ethnic minorities in the post-9/11 United States and provides a humorous, exaggerated and very entertaining look at the machinery of show business. Hanan, an aspiring Lebanese singer signs a contract with a major recording studio whose only condition of mutual collaboration is that she be revamped and promoted as a Latina artist (taking the cue from the likes of Jennifer Lopez). Anything even remotely Middle Eastern is bad for popularity and business. In a series of slapstick comedy and sudden twists, Hanan finds her happiness in the arms and loving care of a female cleaner.

Although the production is distinctly in the category of traditional theatre, with a written dramatic text and conventional dramaturgy, its theme resonates with the audience the Mixed Blood Theatre is trying to attract - the partly Ethiopian, partly Somali minority living in the theatre's proximity, university students of diverse origin, as well as members of various Minneapolis ethnic minorities (mostly Asian, Middle Eastern and African American). The political implications of ethnic and sexual identity are examined through a series of absurd, over-the-top scenes that aspire to make the audience laugh and subsequently contemplate the social relevance of the presented absurdities.

The Mixed Blood Theatre has been an active element in the life of the community of neardowntown Minneapolis for almost 40 years. It performs around 500 shows every year and deals predominantly with community issues (such as the mixed blood of its members and the resulting cultural circumstances), using theatre that abounds in political satire, is stimulating, supportive and inclusive, and presents to its audiences its ambition to make truly global theatre. Using a programme called Radical Hospitality, the Mixed Blood Theatre allows people who normally would not be able to pay for a theatre ticket to see their shows. By combining relevant topics, entertaining presentation and an inclusive ticketing policy, Mixed Blood has been enormously successful at what Sonja Kuftinec calls "animating and including community participants" while at the same time "[appropriately representing] traumatic events" and reflecting on "institutional relationship to power" (Kuftinec, 2003, p. 17).

The dramaturgical approach at Mixed Blood allows for innovative ways of staging and representing ethnic, racial and social issues. Mixed Blood distinguishes itself from the creative practice of most large scenes in Minneapolis by not racially or ethnically framing their productions and by not succumbing to the temptation of typecasting their characters accordingly. This is a political decision in many respects, recognized by Baz Kershaw who claims that for such theatres "[the] starting point [is] the nature of their audience and its community [and that] [t]he aesthetics of their performances [are] shaped by the culture of their audience's community" (Kershaw, 1992, p. 5). 


\section{Bending the Circle}

The Pangea World Theater, established in 1995, is a company whose community outreach is very broad and very diverse. Their focus is on political issues and human rights, presented in a variety of artistic forms and related to the issues their community faces. Through its theatrical productions and social work Pangea communicates a strong "desire that voices will be heard that are most often not heard in the mainstream theatre; that issues will be discussed that are very seldom discussed; that through the interactive process, the community will have a dialogue about solutions to the issues with which it is struggling" (Diamond, 2007, p. 58). For Pangea, high-brow aesthetics and dramatic professionalism are only secondary to the focus on social and political engagement.

Pangea's 2012 production Outside the Circle is a devised piece presenting the story of two "freaks of nature" - a lesbian and a man with cerebral palsy - who meet in a bar to discover and face their own stereotypes and tendencies towards intolerance. The performance was created by Andrea Assaf and Samuel Valdez (both playing basically themselves) in an attempt to capture the limits and false impressions of what is considered normal, natural and acceptable. By doing this, the production is bending the circle used to delineate who is an insider and who an outsider - but bending it in both directions. Assaf's character has to come to terms with her own manifestations of intolerance towards a man with a physical disability - intolerance which is very similar to what she herself is used to. Valdez's character also ends up redefining his own level of responsiveness to otherness.

Outside the Circle is an example of the multifarious work produced by the Pangea World Theater which, in a manner similar to Mixed Blood, communicates its focus on social diversity and a multicultural approach already through its name. Just like Mixed Blood's effort to make global theatre, Pangea aspires to produce theatre that is international and that reflects on issues related to the human condition, human rights and civil liberties. The company produces and co-produces several shows every year.

Besides theatre, Pangea is involved in a number of cultural activities and organizes events that range from the artistic to the educational. An example of the latter is an initiative called Diverse Stages which uses the medium of the school theatre to discuss issues relevant for the youngest generation. The initiative strives to challenge and redefine conventional approaches to arts education, critical literacy, aesthetics, theory and criticism. Pangea's artistic and educational projects seek to walk a fine line between entertainment, engagement and efficacy, thus imbuing their production with the meaning of community, or grassroots theatre which is "not just [about] the play but the play in its community context" (Leonard, Kilkelly \& Burnham, 2006, p. 5).

\section{Buzzers and Icebreakers}

The community of Uptown Minneapolis is as varied as its many neighbourhoods. This diversity is mirrored in the artistic production and social work of the Pillsbury House Theatre, established in 1992, a vibrant and functional community and arts centre. It supports and produces children's theatre as an instrument of learning and a catalyst of creativity and critical thinking, but its main line of artistic output lies with the professional theatre productions regularly put on by well-known playwrights, directors and performers.

The showcase production of the 2012 season in the Pillsbury House Theatre was the world premiere of Buzzer, a play commissioned by Pillsbury and written by renowned African American playwright Tracey Scott Wilson. An examination of the illusion of post-raciality in the United States, the play addresses a multitude of issues that are directly related to the experience and expectations of the Pillsbury audience, such as the changing nature of their neighbourhoods, gentrification, revitalization and development, but also racism, sexism, gender issues and cultural differences. The play not only established what Kershaw calls "an 
ideological transaction between a company of performers and the community of their audience" (Kershaw, 1992, p. 16) but also generated sufficient emotional and intellectual energy for the spectators to enter into an engaging post-performance discussion. Suk refers to this as "a confluence of energies [and] ideas" - a state in which both the performers and the audience experience "pure existential flux" resulting from the "social and physical union" between the actors and spectators (Suk, 2011, p. 148).

However, community theatre does not only aspire to facilitate ideological transactions aesthetic, story-telling and entertainment factors are also relevant for community audiences (Haedicke \& Nellhaus, 2001, p. 34). With Buzzer, the Pillsbury House Theatre succeeded in producing a show that allowed the audience to co-determine the meaning, interpretation and social relevance, while putting forward issues that have long been part of the racial (and, arguably also post-racial) discourse. The play uncovered latent complications in the postracial sentiment of mostly urban population (such as the one in Uptown Minneapolis) and became one of the contemporary dramatic works that "[exposed] the unacknowledged, normalizing operations of racism" and allowed the performance "to undermine the fictional wholeness of dominant identities" (Jackson, 2004, p. 181).

In a manner similar to the activities of the Mixed Blood Theatre and the Pangea World Theater, Pillsbury House extends its endeavour to social work through the arts. Their Breaking Ice initiative is focused on businesses and corporations, and offers a creative and theatrical approach to address issues of communication, tolerance and diversity in the everyday business activities of companies. This crossover of artistic engagement closes the circle of community work because it brings together education, professional performance, and economic and social goals.

\section{Imaginative, Useful and Efficient}

In his 1975 essay Drama in a Dramatised Society, Raymond Williams argues that with the omnipresence of drama in the media as well as in social and cultural events, people experience a "dramatisation of consciousness" when politicians, for example, claim (rather dramatically) to be speaking on behalf of the entire nation (Williams, 1975, p. 15). In Williams's view, the need for drama (not to mention performance) seems to have diminished with an increasingly dramatized reality. Communities thus fall short of being able to connect the presented issues with their particular concerns. In other words, drama and dramatized events lack what Kershaw and other theorists call "efficacy" and what "[can enable] the community to see the usefulness of performance to its interests" (Kershaw, 1992, p. 66). Mixed Blood, Pangea and Pillsbury House all try to maintain a high level of usefulness and relevance of their artistic production to the community. The shows might be traditional in terms of aesthetics, dramaturgy, or directorial/acting approach, but they always relate explicitly to the concerns of the community in question.

At the same time, however, there is one considerable drawback to the content- and issuerelated exclusivity of community-based theatre which, quite paradoxically, is co-responsible for its exclusion from the mainstream. Critics and theorists have recognized this phenomenon as both a co-defining element of community theatre and a problematic point in a potentially wider acknowledgement of this type of theatre's artistic and social value. Eugene van Erven, for example, identifies community theatre as "moving, pertinent, powerful, and effective in strengthening the groups of people it caters to," and simultaneously concedes that "because [community theatre] mostly manifests itself in out-of-the-way places, this art is often ignored by inner city elites, by policy-makers, and by cultural commentators" (Erven, 2001, p. ix). Kuftinec, in a similar observation, posits that "[the] visibility of community-based theater" is "submerged" by "[t]he logocentrism of theater studies [that] privileges the dramatic text and the written remnants of critical reports" (Kuftinec, 2003, p. 16). A part of the concern here 
lies in the insufficiency (or incompatibility) of theory-based criticism and the extremely cross-disciplinary nature of community-based art productions which can range from drama, performance, parade or happening, to educational activities, even to public or academic discussions.

In community-based theatre, spectators can step over the threshold of a merely aesthetic perception of art. This, in turn, can enable them to see the social and political appeal of community-based theatre as the primary goal of the productions or performances. At any rate, in a community-based and socially committed arts environment, theatre fulfils the function of bringing people together not because they are united through an aesthetic tradition, or through a shared political and social history, or perhaps because they are of the same racial, ethnic or social group, but because they are defined by what Bauman aptly calls "togetherness": "We may say that 'community' is a short-cut to togetherness, and to a kind of togetherness which hardly ever occurs in 'real life': a togetherness of sheer likeness, of the 'us who are all the same' kind; a togetherness which for this reason is unproblematic, calling for no effort and no vigilance, truly pre-ordained; a kind of togetherness which is not a task but 'the given', and given well before any effort to make it be has started" (Bauman, 2000, p. 99-100).

The "unproblematic" nature of this togetherness lies in the recognition of any particular community as a complex and vital entity - one that not only shares numerous common features (as well as contradictions and discrepancies) but also (perhaps primarily) rests on its members' ability to imagine things and empathize with others. Imaginative and empathetic communities are what healthy societies can rely on.

\section{Works cited:}

Anderson, B., 2006. Imagined Communities: Reflections on the Origin and Spread of Nationalism. London, New York: Verso.

Bauman, Z., 2000. Liquid Modernity. Cambridge: Blackwell.

Cohen-Cruz, J., 2005. Local Acts: Community-based Performance in the United States. New

Brunswick: Rutgers University Press.

Diamond, D., 2007. Theatre for Living: The Art and Science of Community-based Dialogue. Victoria, Oxford: Trafford.

Dolan, J., 2005, Utopia in Performance: Finding Hope at the Theater. Ann Arbor: University of Michigan Press.

Erven, E.v., 2001. Community Theatre: Global Perspectives. London, New York: Routledge.

Haedicke, S.C. \& Nellhaus, T., 2001, Performing Democracy: International Perspectives on Urban Community-based Performance. Ann Arbor: University of Michigan Press.

Jackson, S., 2004. Professing Performance: Theatre in the Academy from Philology to Performativity.

New York: Cambridge University Press.

Kershaw, B., 1992. The Politics of Performance: Radical Theatre as Cultural Intervention. London, New York: Routledge.

Kuftinec, S., 2003. Staging America: Cornerstone and Community-based Theater. Carbondale:

Southern Illinois University Press. 
Leonard, R.H., Kilkelly, A. and Burnham, L.F., 2006. Performing Communities: Grassroots

Ensemble Theaters Deeply Rooted in Eight U.S. Communities. Oakland: New Village Press.

Suk, J., 2011. "Seeing the Seeing the Seeing: Understanding the Spectatorship of Forced

Entertainment." In: American \& British Studies Annual, Vol. 4, No. 1, pp. 146-157.

Suk, J., 2014. "Stepping Off the Empty Stage: Live Art Aspects in Bloody Mess.” In: Hradec Králové Journal of Anglophone Studies, Vol. 1, No. 1, pp. 55-62.

Thomson, J. \& Schechner, R., 2004. “Why ‘Social Theatre'?” In: TDR, Vol. 48, No. 3, pp. 11-16.

Williams, R., 1975. Drama in a Dramatised Society. Cambridge: Cambridge University Press.

Mgr. Ivan Lacko, PhD

Dept. of English and American Studies

Faculty of Arts

Comenius University in Bratislava

Gondova 2, 81499

Bratislava

Slovakia

lacko@fphil.uniba.sk

Publication of the article was supported by a grant of the project KEGA 039UKF-4/2012 Vyučovanie súčasných anglofónnych literatúr ako prostriedok posilňovania kreativneho a kritického myslenia.

\footnotetext{
i Throughout this paper I use the terms "community theatre", "community-based theatre", and "social theatre" interchangeably, notwithstanding the connotative and technical differences in their meaning.
} 